\title{
Exploring The Significance of Proverbs in English Language
}

\author{
Mukhalad Malik \\ Cihan University \\ (Email: mukhalad72@yahoo.com)
}

\section{Key Words:}

Proverbs

Speech acts

Functions

Meanings

Communicative

Significance

\section{ABSTRACT}

Proverbs are by far the richest man's prominence being a privilege and a multifaceted reflection of communication activities. They serve the presence of an ongoing process of mentality as effective spoken or written instruments conveying countless senses, intentions, experiences, purposes and so on. This paper aims to explore the significance of proverbs at various levels of communications through a thorough depiction of the essential traits and various possible inherent and intended meanings which they convey. It is mainly concerned with viewing the communicative significance of proverbs through involving them to the possible speech acts they intend to provoke and through expounding the multiple congenital meanings which they imply when used in a communicative situation. It can be explicitly demonstrated through this paper that proverbs are used as an intrinsic estimation of the communication process emphasizing different values of instructive functions, moral considerations, knowledges, wisdoms and experiences at and for the will of human being.

\section{ABSTRAK}

Atikel ini bertujuan untuk mengeksplorasi pentingnya peribahasa di berbagai tingkat komunikasi melalui penggambaran menyeluruh tentang sifat-sifat penting dan berbagai kemungkinan makna yang melekat dan dimaksudkan yang mereka sampaikan. Hal ini terutama berkaitan dengan melihat signifikansi komunikatif dari peribahasa dengan melibatkan mereka dalam kemungkinan tindak tutur yang ingin mereka provokasi dan melalui menguraikan berbagai makna bawaan yang mereka maksudkan ketika digunakan dalam situasi komunikatif. Dapat secara eksplisit ditunjukkan melalui makalah ini bahwa peribahasa digunakan sebagai estimasi intrinsik dari proses komunikasi yang menekankan nilai-nilai yang berbeda dari fungsi instruktif, pertimbangan moral, pengetahuan, kebijaksanaan dan pengalaman di dan untuk kehendak manusia.
Mukhalad Malik

Exploring The Significance of Proverbs in

English Language
(30)

ALSUNA Vol. 2 (1), 2019

http://e-journal.ikhac.ac.id/index.php/alsuna https:// doi.org/10.31538/alsuna 


\section{Introduction}

Proverbs, presumably, are a reflection of the most powerful resources which language make available whenever humans are prepared to reach the utmost atmosphere of elegance. Shaping the language figuratively and non-literally may touch a level beyond language itself. In fact, proverbs would be described as one of the most important utilizations in English getting an increased consideration at the basic levels of language understanding, teaching and learning. In the broadest sense, they are the precious products of human thoughts, realities, attitudes, feelings and beliefs. Such a broad area of human experience has made proverbs universally accepted. The present paper tackles the various speech acts which they implicitly or explicitly express and, hence, it is concerned eventually with viewing their possible envisioned senses and their significance when used in any communicative event. To get an efficient plausibility of the force of proverbs, the paper is coloured with various thematic groups of proverbs on society, justice, weather and other kinds. The reason behind quoting various kinds of proverbs is to elaborate and enhance the validity that proverbs have indeed communicative significance and value when used in communication being an impressive and widely used tool of expression in language. According to Whiting, a proverb is " An expression which owing its birth to the people, testifies its origin in form and phrase.

It expresses what a fundamental truth is apparently in a homely language, often ornamented, however, with alliteration and rhyme (Whiting, 1983). In a more general sense, proverbs are described as "self -contained, pithy, traditional expressions with didactic content and fixed, poetic form "By self -contained is meant that their grammatical units can't be replaced by other units e.g., the sentence "curiosity killed the cat" cannot be replaced by another phrase (Norrick, 1985, p, 31).

\section{Discussion}

A proverb is usually sightless unless pragmatics encompasses the entire vision of what, how why and where it could be. This is absolutely reliable knowing that pragmatics comprises the type of meaning that goes beyond what is said literally. That is, the type of meaning intended by the speaker when, for instance, using a proverb in a certain situation and inferred 
by the hearer only in terms of the context in which this proverb is used. The uttering of a certain proverb may encompass the enactment of two consistent acts (formal and intentional). Stiles stats that "the formal act is overtly conveyed by the structural level of language; the latter is covertly induced from the context. The most important act is the intentional one because it shows clearly how the utterance is "taken to be" as well it is the one that implies the type of meaning intended by the speaker and the intentional act is often performed by the proper used proverb"(Stiles, 1980, p, 234). Akmajian et al. ensue that it is so obvious that proverbs are not used both literally and directly; they are often employed both nonlinearly and indirectly because people usually avoid directing their audience and choose proverbs to soften the effect by distancing themselves from the advice or warning (Akmajian et al., 2001, p.387). This clearly shows that proverbs are basically to be interpreted within the scope of speech acts. The most important point to consider when discussing the issue of proverbs in terms of speech acts is the belief that when using proverbs in certain situation it does not mean at all that uttering words of that proverb but performing linguistic acts for a certain communicative purpose which is proper to the situation in which it is uttered. Ultimately proverbs are statements that function as deeds.

The following are chosen proverbs with their significant use, meaning, interpretation and possible influence. "Rainbow in the morning gives you fair warning.", under certain appropriate conditions, does not define the weather state but essentially offers the listener or addressee a gentle warning (i.e., fair rain will be approaching).

While enunciating this proverb, three interrelated acts are simultaneously involved: the lectionary, illocutionary and elocutionary acts (which are the major components of a speech act). Verschueren (1999) clarifies that the act of uttering the proverb "Rainbow in the morning gives you fair warning" is referred to as the locution. This act involves the issuing of a well-formed grammatical and meaningful sentence pronounced properly (i.e., the words artificially divorced on the context of utterance). The illocution refers to what is intended in saying this proverb, or what type of speech acts is meant by this proverb. In fact, this proverb is taken to be a fair warning. What this clearly means is the fact that this proverb has the indirect speech act of warning. "Behind the cloud the sun is shining" This proverb can be said in the actual use of language although there may be no clouds at all in the sky. Depending on the situation (or more 
specifically on the social situation) it can be interpreted, pragmatically, as conveying the indirect speech act of fighting slavery and how finally people must be equal in rights treatment and the like. This proverb is cited by one of the American presidents (Eisenhower) who sought justice among people. Apparently, he used this proverb as a social tool for calling for justice expressing his hopes of the rise of justice and equality (Mieder, 2000). "If You Can't Stand the Heat, Get out of the Kitchen." The interpretation of this proverb is that if someone can't tolerate the pressures of a particular situation, he/ she should remove oneself from that situation. This proverb implicitly has the indirect speech act of advice where the use is totally non-literal. Although there is an image of kitchen, it does not refer to kitchen but to an entirely a different issue. It should always be considered that proverbs are the representations of certain context of situation used in certain and specific communicative process. "Who refuses to submit to justice must not complain of oppressions" Pragmatically, this proverb involves the direct speech act of warning. Anyone who does not stick to or follow rules or violate them will be punished which he shouldn't complain of later on. This proverb, according to the communicative event in which it is proper to occur, is warning against anyone who thinks of violating rules, so it is an urge for people not to do so since if they do they will be punished. What can be noticed from the interpretations of those different proverbs is the fact that they clearly to be taken indirectly, they include indirect speech act of warn, advice or call for applying justice. The speech acts of proverbs discussed so far manifest that they have various messages to convey including advice, warning and so on. But what about the lexical component out of which proverbs can see the light?

After all, proverbs are group of lexical components (words) combined together to form larger semantic units, which are encoded by the speaker and decoded by the hearer. Leech draws the attention to the fact that proverbs have their own conceptual meaning which is a basic component of language recognition and estimation and that the conceptual meaning of nearly any item in any language is the same since the conceptual meaning is "a universal property of the mind. (Leech, 1980, p.13). However, this by all means, does not mean that all people show the same conceptual framework, since differences in age, education, etc. play the greatest role. The following proverb shows that the meaning of the key word 'evils' is the logical (or 
referential or denotative) meaning that no two speakers would differ about: "Of two evils choose the least." The possible interpretations of words that compose the entire conceptual meaning of proverbs have other important characteristics because of the fact that they are associated with ideas of human experience but only when they are used in certain communicative situation. This is termed 'associative meaning', which can be of several types of meanings, the most important of which are connotative, affective, stylistic and collocative meanings. This variety of associative meaning is as a result of the diversity of the individual experience. But when proverbs being manifested as an embodiment of literary style, Gairness and Redman illustrate that they frequently consist of the association of ideas due to collocation. Collocation could be normal or unusual. Writers use the latter type at times for creating stylistic effects to impress readers. Of course, there are inexorably variances of judgment as to what represents an acceptable collocation in English or whether the semantic function of the collocated words in the proverb can be fully deductible from the meaning of the individual words. However, the collocations that we are referring to in the following proverbs are of the normal type, depending mainly on oppositeness of meaning and that no two persons would disagree about their validity: "As you sow, so will you reap." (Gairness, \& Redman, 1986).

\section{Results}

Regardless of the type of the speech act or the potential meaning that proverbs may have, the major and most important fact to be stated is that they have certain functions to achieve when they are used in certain communicative situation. Proverbs and proverbial sayings, with their communicative significance and value, have for centuries been equally popular with all nations due to the enormous significance and function which they intend to carry and due to the influence they have made. Their inspiring significance in communication, the teaching they give, which ranges from general truths of advice, warning and comments they offer on human experience, encourage humans to act and behave in certain ways.

While trying to analyse the functions of proverbs it is a prerequisite to bear in mind how traditional proverbs carry on to be employed and function in modern world. As Mieder (2000) demonstrates. Doubtlessly traditional proverbs still play a significant role in today's speech, 
where they continue to be used to moralize, to instruct, to advise, and to reflect on everyday occurrences. Such old well known proverbs are often used in a different new manner; they are changed in order to be efficient in communication at various levels showing a variety of significant functions in society, conversation, interaction and so on. While discussing the significance of proverbs as far as their use in any communicative event is concerned, a crucial question is to be posited: why do people use proverbs at all? Or what is the significance of using proverbs in communication? Taylor clarifies that proverbs don't usually function as mere poetic embellishments of speech, neither are they used to meet man's needs for philosophic phrase mongering. In fact, their use has some practical functions and significance in various circumstances of everyday communication. According to him, 'Men buy and read collections of proverbs to awaken and enlarge reflections on the world and the nature of man, to suggest subjects for conversation, or to provide themselves with comment appropriate to situations in daily life' (Taylor, 1996).

By employing proverbs in our speech we wish to strengthen our arguments, express generalisations, influence or manipulate other people, rationalize our own shortcomings, question certain behavioral patterns, satirize social ills, poke fun at ridiculous situations'. It is not surprising that through the ages proverbs which have prevailed and contributed significantly to the English language still form a living part of it and thus can enrich our everyday conversations. They make the language a more vivid and powerful tool of communication. A response receives an additional weight when we don't speak merely with our own mouths and we don't use our individual expression of state of mind, but a general opinion. In terms of functions, Finnegan states that proverbs have been observed to occur in all communication events and their occurrences proved to be of great significance due to their influence and their effectiveness. They are used in oratory, counseling, judging, embellishing, speeches and enriching conversations (Finnegan, 1994, p. 36).

First of all, proverbs had and still have a didactic function. By using them we wish to teach people, give them some advice, help in difficult situations, show people what are the most important things in life, show the proper way in life. Most proverbs having a didactic function originate as 'Seek and you shall find. When it comes to their significance in communication, it 
can be clearly seen that Proverbs are very often used in personal interaction. They can function as warning ('Keep your weather eye open', 'Mind your $P^{\prime}$ s and $Q$ 's' ), suggestion ('Live and let live', 'It is never too late to learn'), scolding ('He that seeks trouble, never misses it', 'He struts like a peacock' ), explanation ('He who lives by the sword dies by the sword'), justification ('Too many cooks spoil the broth'), a summary or a comment ('Learn wisdom by the follies of others', 'Care killed the cat'). They also bring out the essence of a given phenomenon, warn of danger, tell people how to behave and how to not behave, advise or give direct orders and prohibitions. With the aid of proverb one can aim to provide an endorsement to his statement or opinions, forecast something, express doubts, accuse someone of something, jeer at somebody's misfortune, justify or excuse somebody. Proverbs are also used to sum up life experiences and let the listener draw conclusions by himself and apply them to his behaviour in the future. Mostly, the use of proverbs is deemed significant at various communicative events. They are considered an impressive and influential tool by means of which it is possible to bring into disrepute or mock someone or criticise someone or a situation.

\section{Conclusion}

Linguistically, proverbs are groups of words which maybe a phrase or a sentence expressing a concise and complete thought. They are of various types and comprise all fields of life. Irrespective of their variety, they implicitly have multiple speech acts which are in most cases indirect. The words which compose proverbs have several indications and vary in accordance with the used proverb in a given situation. The most significant aspect of proverbs is the fact that they are used to perform specific aspect in the communicative process. Their functions in language are of great importance as they urge actions, increase knowledge and draw the attention to facts and truths. In communication, their significance appears to be a crucial part of human interactions, conveying ideas, emphasizing meanings and so on. The understanding of proverbs, their use and their communicative significance are an essential part of an efficient language understanding and, hence, an efficient language use. If the study of language is a prerequisite to get knowledge about that language, then the study of proverbs is a prerequisite to understand what language can express, convey and mean when people of that 
language use it in various situational contexts. Proverbs are not only a reflection of humans' own language; they are a reflection of humans themselves.

Mukhalad Malik

Exploring The Significance of Proverbs in English Language
ALSUNA Vol. 2 (1), 2019 https://doi.org/10.31538/alsuna 


\section{Bibliography}

Akmajian, A.; R. Demers; A. Farmer and R. Harnish. Linguistics: An Introduction to Language and Communication. Cambridge: The MIT Press, 2001.

Finnegan, R. "Proverbs in Africa." In The Wisdom of Many: Essays on the Proverb. (Eds): Wolfgang Mieder and Alan Dundes". New York: Garland, 10-42, 1994.

Gairness, R. and Redman, M. Working with Words. Cambridge: Cambridge University Press, 1986

Leech, G. Semantics. Harmondsworth: Penguin Books limited, 1980.

Mieder, W. Proverbs: A Handbook: Greenwood: Folklore Handbooks, 2000.

Norrick, N. How Proverbs Mean: Semantic Studies in English Proverbs. Berlin: Mouton Publishers, 1985.

Stiles, W. "Classification of Intersubjective Illocutionary Acts. Journal of Language in Society-Vol. (1). P. 233-249, 1980.

Taylor, A. The Study of Proverbs. Cambridge: Cambridge University Press, 1996.

Whiting, Bartlett, J. Proverbs in Earlier English Drama with Illustration from Contemporary French Plays. Cambridge Mass: Harvard University Press: New York; 10. Octagon Books, 1983.

Vershueren, J. Understanding Pragmatics. London: Arnold, 1999.

Mukhalad Malik

Exploring The Significance of Proverbs in

English Language
(38)

ALSUNA Vol. 2 (1), 2019

http://e-journal.ikhac.ac.id/index.php/alsuna https://doi.org/10.31538/alsuna 